\title{
Endoscopic management of blue rubber bleb nevus syndrome: A case report
}

\author{
WEIWEI GUO, ZHAOYUAN PENG, XIAOWEI TANG, ZHIFEI ZHAO and ZHENG LIU \\ Medical Center for Digestive Diseases, Second Affiliated Hospital of Nanjing Medical University, \\ Nanjing, Jiangsu 210011, P.R. China
}

Received April 23, 2013; Accepted August 23, 2013

DOI: $10.3892 /$ etm.2013.1303

\begin{abstract}
Blue rubber bleb nevus syndrome (BRBNS) is a rare disorder characterized by multiple recurrent vascular malformations, including hemangioma, which primarily locate on the skin and gastrointestinal (GI) tract. The present study reports a 22-year-old female with iron-deficiency anemia and recurrent episodes of melena. The patient also exhibited characteristic venous malformations of the skin. Endoscopy revealed several hemangiomas in the GI tract. The hemangiomas were treated by ligation using a nylon cord, while small blue mucosal polypoid lesions were treated using a sclerosing agent during colonoscopy and doubleballoon enteroscopy. The patient was reviewed regularly for three years following surgery and no further bleeding episodes were noted.
\end{abstract}

\section{Introduction}

Blue rubber bleb nevus syndrome (BRBNS) is a rare disorder characterized by multiple recurrent vascular malformations, including hemangioma, which are primarily located on the skin and gastrointestinal (GI) tract (1). Other organ systems that may be affected include the central nervous system (2), liver, kidney, bladder, heart, thyroid and spleen. However, these are affected less often than the GI tract (3). Although cases that appear to have an autosomal dominant transmission have been reported $(4,5)$, the majority of cases are sporadic with no family history of the disorder $(6,7)$. Cutaneous angiomas are blue or purple, soft, rubbery, sessile, 'nipple-like' nodules with wrinkled and hyperhydrotic surfaces. However, they may also lie deep in the skin and appear as bluish macules (8).

Correspondence to: Professor Zheng Liu, Medical Center for Digestive Diseases, Second Affiliated Hospital of Nanjing Medical University, 121 Jiangjiayuan, Nanjing, Jiangsu 210011, P.R. China E-mail: lzhgww@163.com

Key words: blue rubber bleb nevus syndrome, hemangioma, gastrointestinal hemorrhage, endoscopic management
A variety of therapeutic strategies have been proposed for the management of GI bleeding in BRBNS, including antiangiogenic agents and surgical resection (9-18). However, no particular method has been demonstrated to be reliably effective in reducing bleeding or controlling blood loss permanently. Furthermore, surgical resection has been condemned as overly aggressive and unhelpful due to the theory that lesions may recur after removal (16). Endoscopy is considered a less invasive alternative for the treatment of BRBNS.

\section{Case report}

The informed consent was obtained from the patient. In March 2012, a 22-year-old female with iron-deficiency anemia, secondary to recurrent episodes of melena, presented as an outpatient to the Department of Gastroenterology at the Second Affiliated Hospital of Nanjing Medical University (Nanjing, China). Since infancy, the patient had exhibited massive characteristic venous malformations of the skin, which were deep blue, soft, rubbery and easily compressible. Between 1991 and 2012, the patient had a history of recurrent GI bleeding and iron-deficiency anemia. The patient did not have any history of non-steroidal anti-inflammatory drug use or peptic ulcers. The patient had received several blood transfusions and, at 12 years of age, an abdominal surgery was performed to resect the hemangiomas in the stomach. A pathological report revealed hemangioma. According to laboratory examinations, the patient exhibited a hemoglobin level of $41.0 \mathrm{~g} / 1$, a red blood cell count of $2,410 / \mathrm{mm}^{3}$, a reduced white blood cell count and an increased neutrophil granulocyte count. Skin lesions of various sizes occurred on the abdomen, hip and leg of the patient (Fig. 1). The patient received a blood transfusion and hemostatic therapy. Following hemostatic therapy, a fecal occult blood test yielded negative results. In order to detect the origin of the hemorrhage, a colonoscopy and capsule endoscopy were performed. Endoscopy revealed several strawberry-like mucosal polypoid lesions with abundant vasculature in the colon and lesions ranging between 8 and $20 \mathrm{~mm}$ were blue-violet and sessile (Fig. 2). Colon lesions were removed in an attempt to eliminate bleeding under colonoscopy. During surgery, hemangiomas were ligated with a nylon cord and several small 

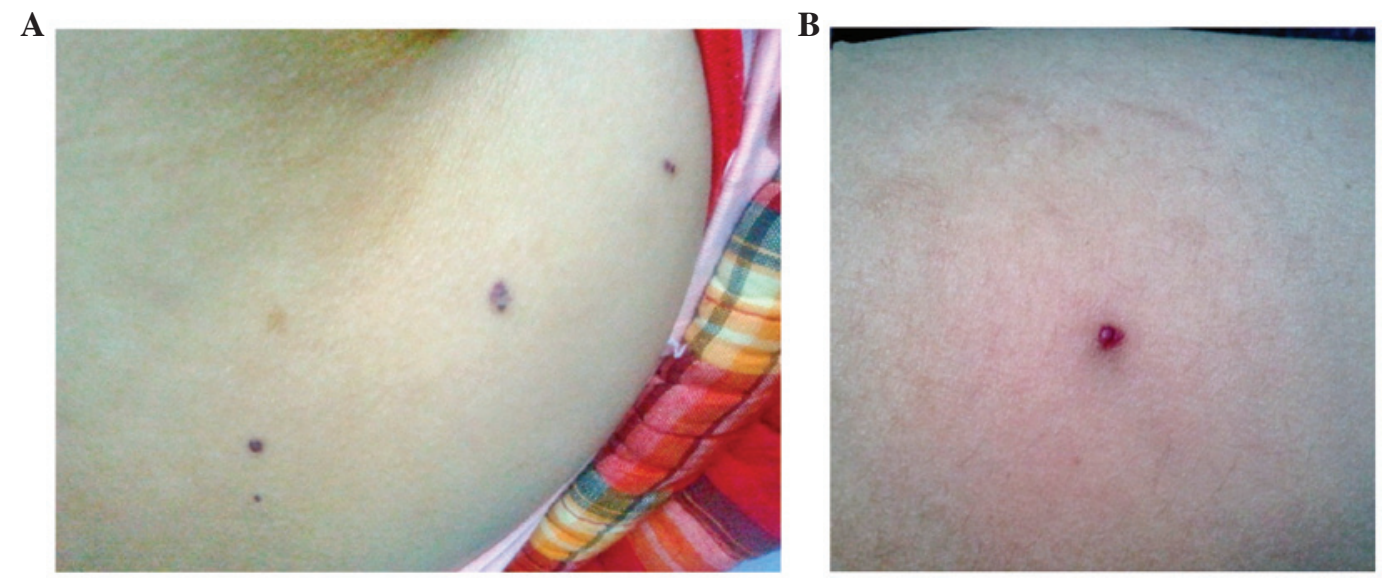

Figure 1. Venous malformations of the skin are deep-blue, soft, rubbery and easily compressible in (A) the hip and (B) the leg.
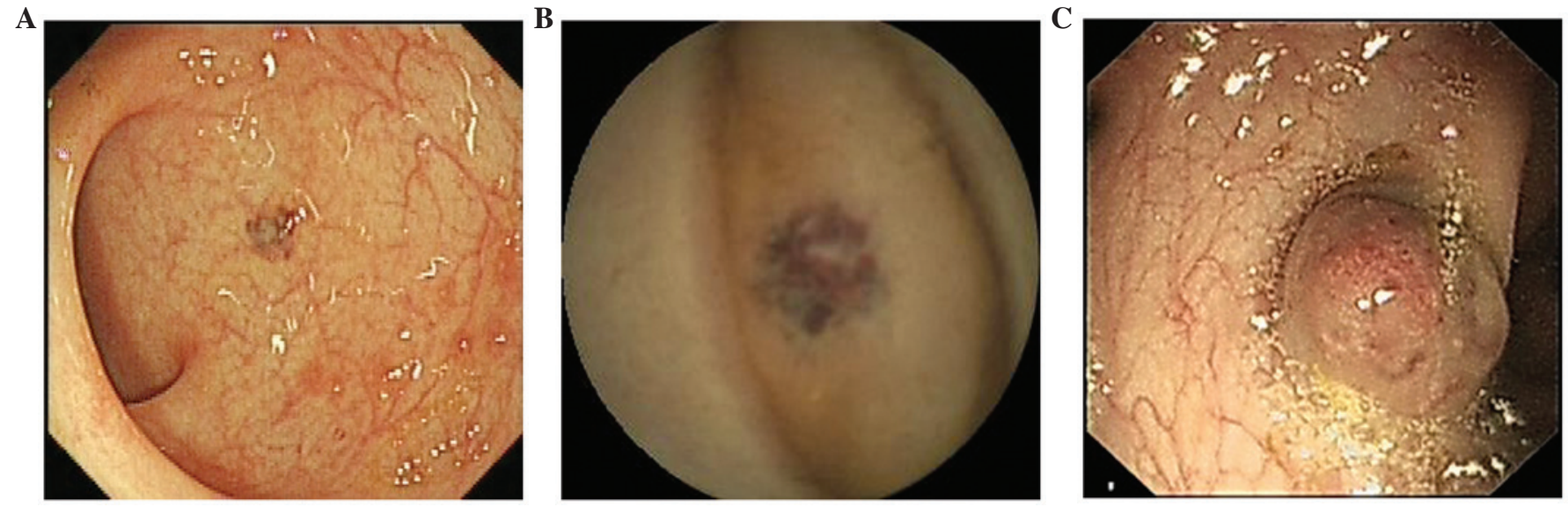

Figure 2. (A-C) Endoscopy revealed several mucosal polypoid lesions with abundant vasculature in the gastrointestinal (GI) tract. The lesions varied in size between 8 and $20 \mathrm{~mm}$.

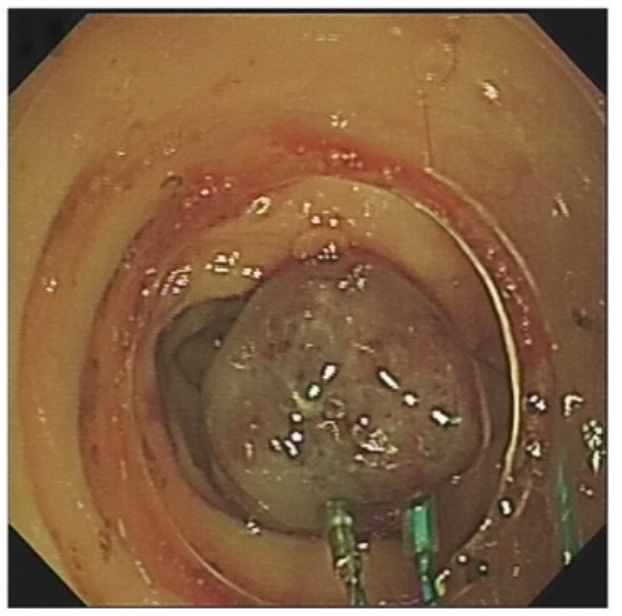

Figure 3. Two small blue mucosal polypoid lesions were treated with sclerotherapy and three hemangiomas were removed using a nylon cord under colonoscopy in the colon transversum.

blue mucosal polypoid lesions were treated with sclerosing agent during colonoscopy (Fig. 3). The patient was discharged in a good condition. A repeat endoscopy at 3 months revealed completely normal mucosa in the original lesions. A number of small lesions that remained were treated with sclerosing agent. Over the subsequent three and a half years, the patient was reviewed regularly and no more bleeding episodes were noted.

We were able to diagnose the patient with BRBNS, according to the cutaneous angiomas and the GI mass lesions that were identified to be hemangiomas. However, it is necessary to differentiate BRBNS from hereditary hemorrhagic telangiectasia, Peutz-Jeghers syndrome, Klippel-Trénaunay syndrome and Maffucci syndrome.

\section{Discussion}

BRBNS is a rare disorder characterized by multiple recurrent vascular malformations, including hemangiomas, which primarily locate on the skin and GI tract (1). Cutaneous angiomas are blue or purple, soft, rubbery, sessile, 'nipple-like' nodules with wrinkled and hyperhydrotic surfaces. However, they may also lie deep in the skin and appear as bluish macules. A number of studies have reported that BRBNS patients experience a gradual increase in pain (19). Pain may be caused by the contraction of smooth muscle 
Table I. Treatments for blue rubber bleb nevus syndrome.

\begin{tabular}{|c|c|c|c|c|c|}
\hline $\begin{array}{l}\text { Year of } \\
\text { publication }\end{array}$ & Author & Therapeutic methods & $\begin{array}{l}\text { Complications related } \\
\text { to treatment }\end{array}$ & Outcome & Ref \\
\hline 1990 & Maunoury et al & $\begin{array}{l}\text { Nd:YAG laser and bipolar } \\
\text { electrocoagulation }\end{array}$ & None & $\begin{array}{l}\text { Avoided hemorrhagic } \\
\text { recurrence of lesions in } \\
\text { the small bowel }\end{array}$ & $(10)$ \\
\hline 1996 & Carr et al & Enterotomies & - & $\begin{array}{l}\text { Stable at follow-up } \\
5 \text { years later }\end{array}$ & (14) \\
\hline 1999 & Sala Felis et al & $\begin{array}{l}\text { Endoscopic treatment by sclerosis } \\
\text { and banding ligation }\end{array}$ & None & Effective & (9) \\
\hline 2001 & Place & $\begin{array}{l}\text { Multiple resectional surgeries } \\
\text { (partial gastrectomy, partial small } \\
\text { bowel resection, total abdominal } \\
\text { colectomy and end ileostomy) }\end{array}$ & $\begin{array}{l}\text { Iron-deficiency, } \\
\text { anemia nephrolithiasis, } \\
\text { major depression, } \\
\text { and malnutrition }\end{array}$ & $\begin{array}{l}\text { Significant long-term } \\
\text { complications }\end{array}$ & (16) \\
\hline 2003 & $\mathrm{Ng}$ and Kong & Argon plasma coagulation & - & $\begin{array}{l}\text { Simple, inexpensive } \\
\text { and effective treatment }\end{array}$ & (13) \\
\hline 2006 & Anzinger et al & $\begin{array}{l}\text { Therapeutic double balloon } \\
\text { enteroscopy }\end{array}$ & None & Effective & $(11)$ \\
\hline 2007 & Okabayashi et al & Laparoscopic surgery & None & $\begin{array}{l}\text { Without iron deficiency } \\
\text { anemia for a year following } \\
\text { the operation }\end{array}$ & (12) \\
\hline 2008 & Emami et al & Endoscopic polypectomy resection & None & Useful & $(18)$ \\
\hline 2010 & Blaise et al & Polidocanol foam sclerotherapy & None & $\begin{array}{l}\text { Technique has not } \\
\text { yet been standardized }\end{array}$ & $(15)$ \\
\hline 2012 & Yuksekkaya et al & Sirolimus & $\begin{array}{l}\text { No drug adverse } \\
\text { reaction at 20-month } \\
\text { follow-up }\end{array}$ & $\begin{array}{l}\text { Vascular masses were } \\
\text { reduced rapidly and } \\
\text { there was no gastro- } \\
\text { intestinal bleeding }\end{array}$ & (17) \\
\hline
\end{tabular}

fibers surrounding the vascular tumors (20). The molecular mechanisms underlying this disease are yet to be fully elucidated. It has been identified that normal endothelial cells of adult vessels do not show c-kit expression, whereas at least partial c-kit positivity has been reported in angiosarcomas (21). In addition, it has been demonstrated that pharmacological inhibition of the c-kit signaling pathway in cavernous hemangiomas by selective kinase inhibitors may offer options in the treatment of BRBNS patients (22). Nobuhara et al (23) identified mutations in the TIE2 gene that encode an endothelial cell tyrosine kinase receptor, which may govern the thickness of the smooth muscle wall of a vessel.

Various treatments for BRBNS are shown in Table I. Progress in endoscopic technology has advanced medical practice concerning the GI tract. Endoscopic diagnosis and treatment of conditions has now supplanted a number of surgical procedures and ongoing technical improvements, and innovations continue to extend the potential for endoscopic therapies (24). In the present case, the patient had exhibited gastrointestinal hemorrhage for 22 years. The patient had received several blood transfusions and iron replacement therapy for anemia by mouth. Endoscopy demonstrated that there were a number of hemangiomas in the GI tract. Further endoscopy was then undertaken to treat the hemangiomas using sclerosis and banding ligation. During a 12-month follow-up, the patient did not exhibit hemorrhage or anemia, and the hemoglobin level was in the normal range.

Surgery is an alternative therapy option. It is an effective method of hemostasis and allows the removal of hemangiomas simultaneously. However, if there are several vascular malformations along the whole digestive tract, surgical methods may not be feasible. Place (16) reported that multiple resectional surgeries (partial gastrectomy, partial small bowel resection, total abdominal colectomy and end ileostomy) resulted in significant long-term complications, including iron-deficiency anemia, nephrolithiasis, major depression and malnutrition. In the present case, endoscopic banding ligation and sclerotherapy were selected. Combined with interferon $\alpha$, GI bleeding in the patient may be controlled effectively. The results achieved were comparable with those of surgery. Therefore, patients are more willing to accept endoscopic treatment than surgical therapy. Endoscopic management of BRBNS may not only increase the quality of life, but may also reduce the medical cost and hospitalization time of patients. 


\section{References}

1. Bean WB (ed): Blue rubber bleb nevi of the skin and gastrointestinal tract. In: Vascular Spiders and Related Lesions of the Skin. Charles C Thomas, Springfield, IL, pp17-185, 1958.

2. Tomelleri G, Cappellari M, Di Matteo A, Zanoni T, Colato C, Bovi P and Moretto G: Blue rubber bleb nevus syndrome with late onset of central nervous system symptomatic involvement. Neurol Sci 31: 501-504, 2010.

3. Nahm WK, Moise S, Eichenfield LF, Paller AS, Nathanson L, Malicki DM and Friedlander SF: Venous malformations in blue rubber bleb nevus syndrome: variable onset of presentation. J Am Acad Dermatol 50 (Suppl): S101-S106, 2004.

4. Gallione CJ, Pasyk KA, Boon LM, Lennon F, Johnson DW, Helmbold EA, Markel DS, et al: A gene for familial venous malformations maps to chromosome $9 \mathrm{p}$ in a second large kindred. J Med Genet 32: 197-199, 1995.

5. McKinlay JR, Kaiser J, Barrett TL and Graham B: Blue rubber bleb nevus syndrome. Cutis 62: 97-98, 1998.

6. Fishman SJ, Smithers CJ, Folkman J, Lund DP, Burrows PE, Mulliken JB and Fox VL: Blue rubber bleb nevus syndrome: surgical eradication of gastrointestinal bleeding. Ann Surg 241: 523-528, 2005.

7. Shin SH, Chae HS, Ji JS, Kim HK, Cho YS, Chang ED and Choi KY: A case of blue rubber bleb nevus syndrome. Korean J Intern Med 23: 208-212, 2008.

8. Torchia D, Schincaglia E and Palleschi GM: Blue rubber-bleb naevus syndrome arising in the middle age. Int J Clin Pract 64: $115-117,2010$.

9. Sala Felis T, Urquijo Ponce JJ, López Viedma B, Pertejo Pastor V and Berenguer Lapuerta J: Blue nevus syndrome: endoscopic treatment by sclerosis and banding ligation. Gastroenterol Hepatol 22: 136-138, 1999 (In Spanish).

10. Maunoury V, Turck D, Brunetaud JM, Marti R, Cortot A, Farriaux JP and Paris JC: Blue rubber bleb nevus syndrome. 3 cases treated with a Nd:YAG laser and bipolar electrocoagulation. Gastroenterol Clin Biol 14: 593-595, 1990 (In French).

11. Anzinger M, Gospos J, Pitzl H, Koletzko S, Heldwein W and Schmitt W: Blue rubber-bleb nevus syndrome and therapeutic double balloon enteroscopy. Z Gastroenterol 44: 1141-1144, 2006 (In German).
12. Okabayashi K, Hasegawa $\mathrm{H}$, Nishibori $\mathrm{H}$, Ishii $\mathrm{Y}$ and Kitajima M: A case of laparoscopic surgery for blue rubber bleb nevus syndrome. Hepatogastroenterology 54: 451-453, 2007.

13. Ng WT and Kong CK: Argon plasma coagulation for blue rubber bleb nevus syndrome in a female infant. Eur J Pediatr Surg 13: 137-139, 2003.

14. Carr MM, Jamieson CG and Lal G: Blue rubber bleb nevus syndrome. Can J Surg 39: 59-62, 1996.

15. Blaise S, Riom H, Charavin-Cocuzza M, Templier I, Zambelli L and Diamand JM: Blue rubber bleb nevus syndrome treated with polidocanol foam sclerotherapy. Dermatol Surg 36: 2067-2068, 2010.

16. Place RJ: Blue rubber bleb nevus syndrome: a case report with long-term follow-up. Mil Med 166: 728-730, 2001.

17. Yuksekkaya H, Ozbek O, Keser M and Toy H: Blue rubber bleb nevus syndrome: successful treatment with sirolimus. Pediatrics 129: e1080-e1084, 2012.

18. Emami MH, Haghdani S, Tavakkoli H and Mahzouni P: Endoscopic polypectomy resection of blue rubber bleb nevus lesions in small bowel. Indian J Gastroenterol 27: 165-166, 2008.

19. Kishikawa H, Okada Y, Kawahara T, Saito K and Tanaka Y: A case of blue rubber bleb nevus syndrome treated by etidronate. J Bone Miner Metab 25: 138-141, 2007.

20. Fine RM, Derbes VJ and Clark WH Jr: Blue rubber bleb nevus. Arch Dermatol 84: 802-805, 1961.

21. Miettinen M, Sarlomo-Rikala M and Lasota J: KIT expression in angiosarcomas and fetal endothelial cells: lack of mutations of exon 11 and exon 17 of c-kit. Mod Pathol 13: 536-541, 2000.

22. Mogler C, Beck C, Kulozik A, Penzel R, Schirmacher P and Breuhahn K: Elevated expression of c-kit in small venous malformations of blue rubber bleb nevus syndrome. Rare Tumors 2: e36, 2010.

23. Nobuhara Y, Onoda N, Fukai K, et al: TIE2 gain-of-function mutation in a patient with pancreatic lymphangioma associated with blue rubber-bleb nevus syndrome: report of a case. Surg Today 36: 283-286, 2006.

24. ASGE Standards of Practice Committee; Early DS, Ben-Menachem T, Decker GA, et al: Appropriate use of GI endoscopy. Gastrointest Endosc 75: 1127-1131, 2012. 